Article

\title{
High-Resolution Monitoring of Glacier Mass Balance and Dynamics with Unmanned Aerial Vehicles on the Ningchan No. 1 Glacier in the Qilian Mountains, China
}

\author{
Bo Cao ${ }^{1,2,3}$, Weijin Guan ${ }^{1,2, *}$, Kaiji Li ${ }^{1}$, Baotian Pan ${ }^{1,2}$ and Xiaodong Sun ${ }^{1}$ \\ 1 Key Laboratory of Western China's Environmental Systems (MOE), \\ College of Earth and Environmental Sciences, Lanzhou University, Lanzhou 730000, China; \\ caobo@lzu.edu.cn (B.C.); likj19@lzu.edu.cn (K.L.); panbt@lzu.edu.cn (B.P.); sunxd20@lzu.edu.cn (X.S.) \\ 2 Shiyang River Basin Scientific Observing Station, Lanzhou University, Lanzhou 730000, China \\ 3 Collaborative Innovation Center for Western Ecological Safety (CIWES), Lanzhou University, \\ Lanzhou 730000, China \\ * Correspondence: guanwj17@lzu.edu.cn
}

check for updates

Citation: Cao, B.; Guan, W.; Li, K.; Pan, B.; Sun, X. High-Resolution Monitoring of Glacier Mass Balance and Dynamics with Unmanned Aerial Vehicles on the Ningchan No. 1 Glacier in the Qilian Mountains, China. Remote Sens. 2021, 13, 2735. https://doi.org/10.3390/rs13142735

Academic Editors: Sergey V. Popov, Gang Qiao, Xiangbin Cui and Nikola Besic

Received: 20 June 2021

Accepted: 9 July 2021

Published: 12 July 2021

Publisher's Note: MDPI stays neutral with regard to jurisdictional claims in published maps and institutional affiliations.

Copyright: (c) 2021 by the authors. Licensee MDPI, Basel, Switzerland. This article is an open access article distributed under the terms and conditions of the Creative Commons Attribution (CC BY) license (https:// creativecommons.org/licenses/by/ $4.0 /)$.

\begin{abstract}
Glaciers located in the Qilian Mountains are rapidly retreating and thinning due to climate change. The current understanding of small glacier mass balance changes under a changing climate is limited by the scarcity of in situ measurements in both time and space as well as the resolution of remote sensing products. Unmanned aerial vehicles (UAVs) provide an unparalleled opportunity to track the spatiotemporal variations in glacier extent at a high resolution and the changing glacier morphological features related to glacial dynamics. Five measurements were performed on the Ningchan No. 1 (NC01) glacier in the Qilian Mountains between 18 August 2017 and 13 August 2020. The glacier changes displayed in the digital orthophoto maps (DOMs) and digital surface models (DSMs) show a $7.4 \pm 0.1 \mathrm{~m} \mathrm{a}^{-1}$ retreat of the terminus of NC01, a mass balance of $-1.22 \pm 0.1 \mathrm{~m}$ w.e. $\mathrm{a}^{-1}$ from 2017 to 2020 , and a maximum surface velocity of $3.2 \pm 0.47 \mathrm{~m}$ from 18 August 2017 to 26 August 2018, which clearly show consistency with stake measurements. The surface elevation change was influenced by the combined effects of air temperature, altitude, slope, and surface velocity. This research demonstrates that UAV photogrammetry can greatly improve the temporal and spatial resolution of glaciological research.
\end{abstract}

Keywords: unmanned aerial vehicles (UAVs); glacier mass balance; glacier surface velocity; Qilian Mountains

\section{Introduction}

The retreat of mountain glaciers around the world is clearly a sign of global climate change [1]. Glaciers provide water for irrigation, power generation, sanitation, and religious activities for large populations and are important parts of rivers in High Mountain Asia (HMA) [2-4]. A continuous negative mass balance results in the decrease in the amount of ice in these mountain ranges [5-8]. Based on current climate projections, glacier mass loss will accelerate and meltwater runoff will increase in the coming decades [9,10]. Therefore, monitoring glacier extent, mass balance, and surface velocity are critical to understanding how climate perturbations affect glaciers [11]. Studies have shown that due to the large number of small glaciers, the impact of their changes is much greater than expected [12]. A deep understanding of small-scale glacier changes can provide a reference for future glacier models and predictions.

Field and geodetic methods can both be used to measure glacier extent, mass balance, and surface velocity, and each method has its own advantages and disadvantages [13]. Field-based glacier monitoring is hampered by glacier inaccessibility, harsh weather, and high costs associated with data acquisition [14]. Satellite remote sensing-based glacier 
monitoring is limited by the spatial and temporal resolution and availability of appropriate data [15], especially in small glaciers. The coarse resolution of most satellite data cannot be applied to calculate the length, area, surface elevation change, and velocity of a glacier [16,17]. Therefore, higher-resolution data are increasingly needed, whether they are related to the glacier dynamics or derived from models of glacier responses to climate change. Recently, cutting-edge technologies such as Terrestrial laser scanning (TLS) and UAVs have been widely used in geodetic mass balance estimates [18-21]. TLS and UAVs have higher precision than satellite images, implying that useful glacier changes can be derived in detail from images acquired over only a few days, even for a small glacier with a slow rate of change. This is a significant advantage because changes in the glacier surface over short time periods have been difficult to obtain [22,23]. Monthly fluctuations in glacier changes can now be observed from time series of UAV images, something that was previously only possible using radar images and only for fast-flowing in large glaciers [24,25]. Compared to TLS, UAVs provide measurements over large areas and can avoid the impact of terrain obscuration with ease and efficiency. In addition, the economic cost of UAVs is much lower.

At present, UAVs are being used by an increasing number of studies in natural science fields $[23,26,27]$. They are economically and technically well suited for surveying glaciers and have been proven to be a very useful glaciology tool [17,28-38]. High-resolution DOMs and DSMs provided by UAVs have made it possible to describe glacier extent, mass balance, and velocity in detail [34], which fills the gap between field and geodetic methods.

Changes in the glaciers in the Qilian Mountains indicate a sensitive response to climate variation [39-43]. In recent years, glaciers in the Qilian Mountains have been quickly retreating, which may have affected the water resources in the Hexi Corridor [40,44]. Glaciers in the Qilian Mountains are small, with an average area of $0.6 \mathrm{~km}^{2}$, and $85 \%$ of the glacier areas are less than $1 \mathrm{~km}^{2}$ [45]. Traditional remote sensing images are difficult to capture the dynamic changes of small glaciers. For this reason, high-resolution data are needed to determine how climate factors affect glacier retreat and to model future glacier mass changes in the Qilian Mountains. In this study, five DOMs and DSMs of the whole Ningchan No.1 (NC01) glacier in the Qilian Mountains were produced after UAV survey flights of the glacier from 2017 to 2020 . The main objectives of this study were (1) to obtain detailed data on glacial area change, mass balance, and surface velocity through UAVs and validate them through independent stake measurements during the same period; (2) to combine multiple factors (air temperature, altitude, slope, surface velocity, etc.) and analyze the causes of dynamic changes in glacier surface elevation.

\section{Study Area}

The NC01 glacier is a mountain glacier located on the north slope of the eastern Qilian Mountains (Figure 1a). It had an area of $0.77 \mathrm{~km}^{2}$ and an altitude range of $4200-4640 \mathrm{~m}$ a.s.1. in 1972 [45]. The annual average temperature is approximately $-6.0^{\circ} \mathrm{C}$, and the mean annual precipitation (MAP) is $>800 \mathrm{~mm}$ based on the automatic weather station on the NC01 lateral moraine (4450 m a.s.1.) [41]. In recent years, NC01 has experienced rapid and accelerated shrinkage $[40,46]$. The mean annual mass balance was approximately -0.7 and -0.9 m w.e. in 1972-2010 and 2010-2015, respectively [41,46]. The mean equilibrium line altitude increased from $4500 \mathrm{~m}$ in 1972 to $4680 \mathrm{~m}$ in 2010-2015 [41,45]. In addition, the area of the NC01 glacier had decreased to $0.39 \pm 0.04 \mathrm{~km}^{2}$ in 2014 [41]. There are several small ice streams and a deep canyons on the exposed ice in ablation season (Figure 1d). NC01 has relatively little debris covering the ice surface, but there are scattered boulders (Figure 1f,g). 


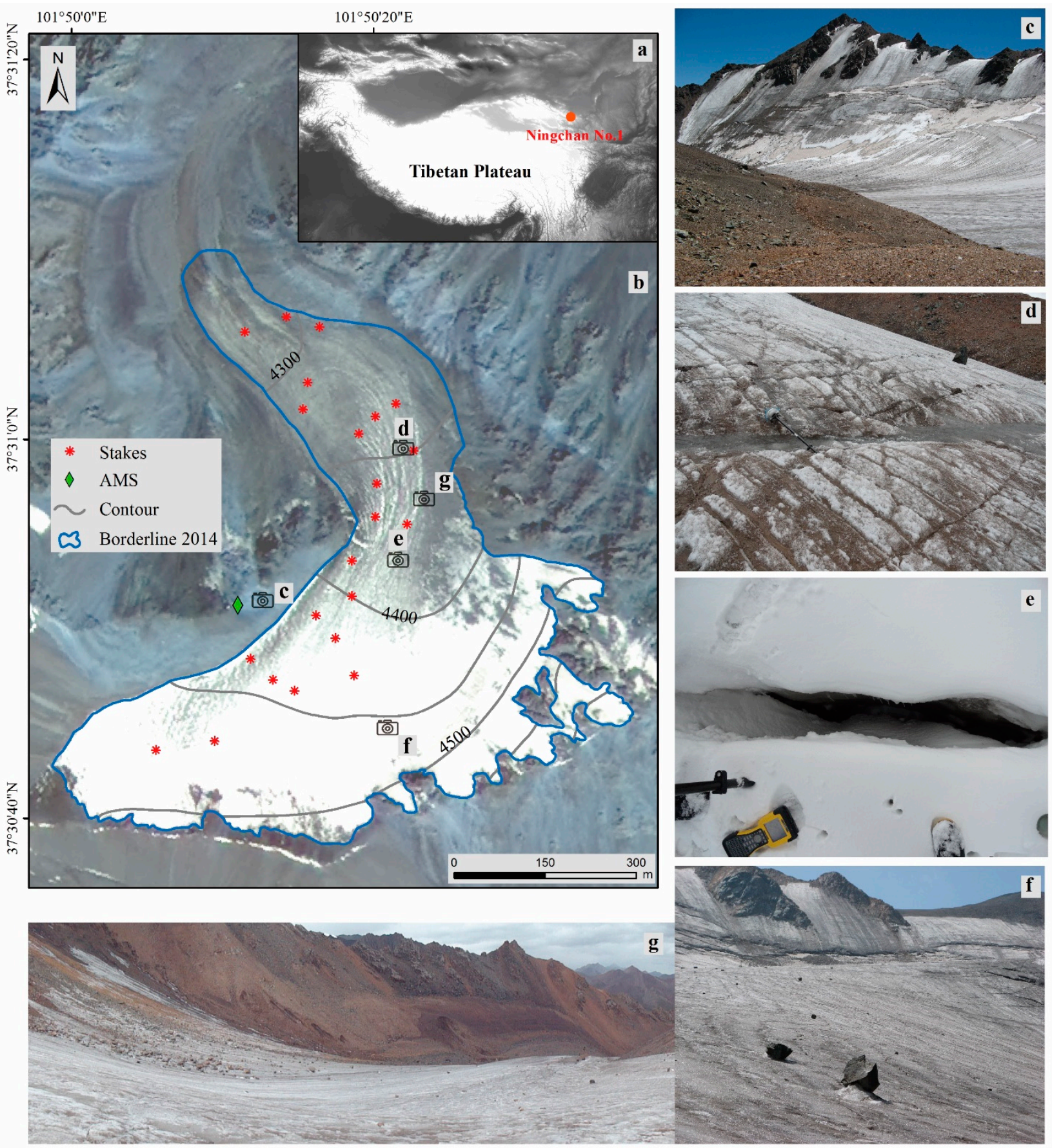

Figure 1. (a) Location of the NC01 glacier on maps of the Tibetan Plateau; (b) overview of the NC01 glacier in 2014 as shown in a satellite remote sensing image; $(\mathbf{c}-\mathbf{g})$ details of the NC01 glacier surface.

\section{Data and Methods}

\subsection{Unmanned Aerial Vehicle Surveys}

The Phantom 4 Pro quadcopter system equipped with a 20 megapixel fixed-lens camera from Dajiang Company was used in this research. It is a rotorcraft that can fly for approximately 20 min with each battery charge.

Five UAV surveys of the entire NC01 glacier region were performed on 18 August 2017, 18 July 2018, 26 August 2018, 18 August 2019, and 13 August 2020 (they are referred to below as 18 August 2017, 18 July 2018, 26 August 2018, 18 August 2019, and 13 August 2020, respectively). Each survey consisted of for flights to cover NC01 and were conducted between 10:00 and 12:00 Beijing time to maximize the flight stability and image quality, as 
the wind speeds usually increased during the day, especially after 14:00. The flights were planned using the DJI-GS-Pro flight planning software to maintain $66 \%$ lateral overlap and $88 \%$ longitudinal overlap between the images. And the average flight height was about $150 \mathrm{~m}$.

\subsection{Orthophotos and Digital Surface Models Generated from $U A V s$}

Images ( $n \approx 2300$, Figure $2 a$ ) collected by each UAV survey were processed into DOMs and DSMs of the glacier and the surrounding environment using a structure-from-motion photogrammetry (SfM) workflow [47]. Further details on the SfM process can be found in Immerzeel et al. [29], Kraaijenbrink et al. [30], Wigmore and Mark [33], Rossini et al. [34], Verhoeven [48], and Kraaijenbrink et al. [49]. The camera positions and the orientation of each image and the image overlap were initialized using the GPS coordinates recorded by the UAV. Due to the influence of reconstruction error, there was some interference in the sparse point cloud. All points with a reprojection error greater than 0.5 pixels were removed [17]. The dense point cloud was used to construct a DSM with a resolution of $0.1 \mathrm{~m}$ (Figure 2c). In addition, a DOM with a resolution of $0.1 \mathrm{~m}$ was created using elevation information (Figure 2b).
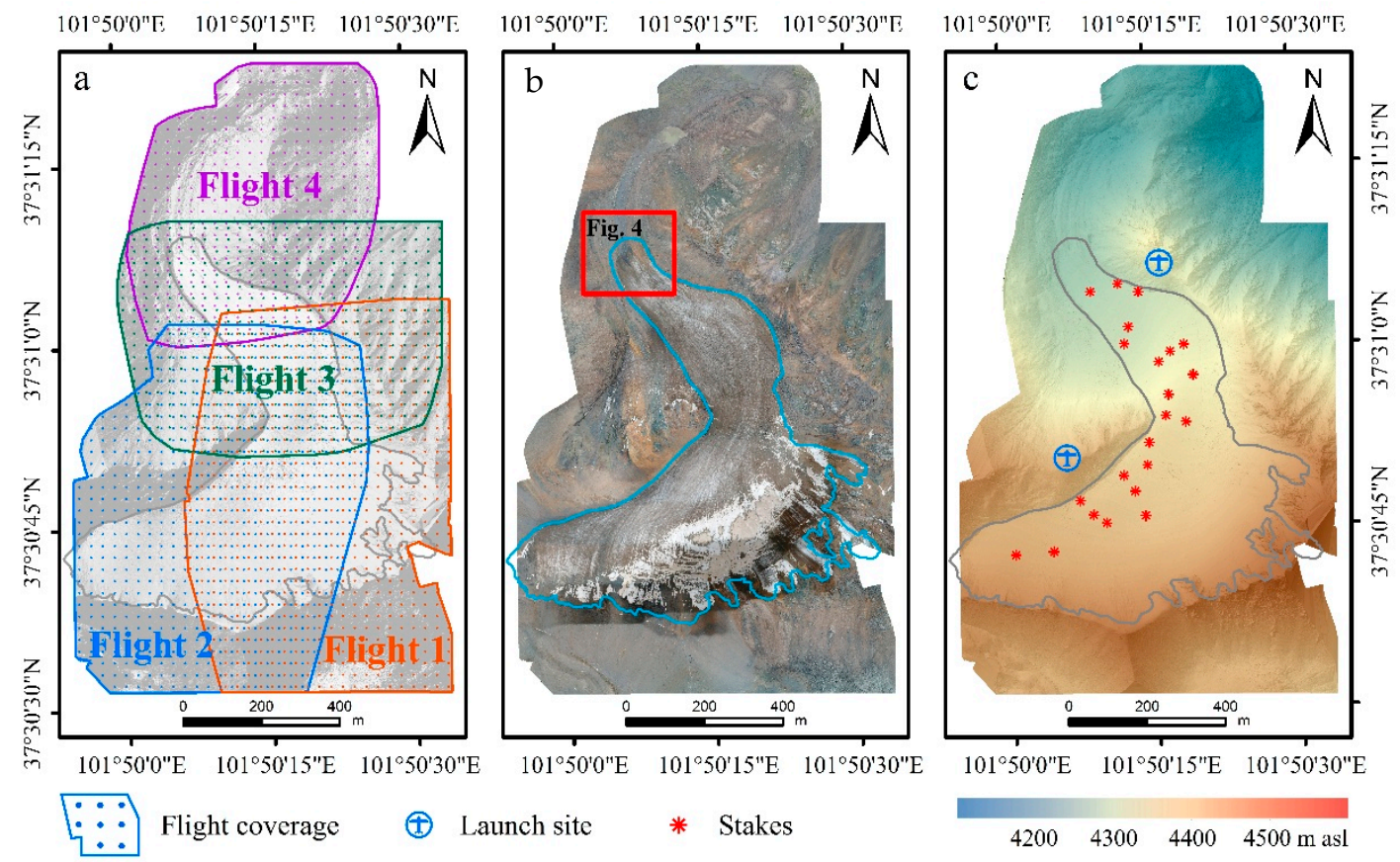

Figure 2. (a) Coverage of the four UAV flights performed during each UAV survey; (b) DOM obtained by SfM image processing; (c) DSM obtained by SfM image processing and the locations of the UAV launch sites and stakes.

\subsection{Glacier Extent, Mass Balance and Surface Velocity Derived from UAVs}

Before any differential analysis, the multitemporal orthophoto images and the corresponding DSMs needed to be comatched to remove the horizontal or vertical offsets [50]. A common method that was proposed by Nuth and Kääb [51] was used here. This method adjusts the relationship between the DSM elevation differences and the aspect in the regions outside of glaciers and further adjusts the correlation. Based on this approach, in each pair of DSMs, one DSM was used as a reference ("master") and the other DSM was used as a "slave". The "slave" DSM moves iteratively along the $\mathrm{x}-, \mathrm{y}$ - and $\mathrm{z}$-axes in pixel fractions to minimize the standard deviation of elevation differences from the "master" DSM $[52,53]$. Shifts along the $\mathrm{x}$ - and $\mathrm{y}$-axes are the also performed in the corresponding orthophoto images.

Even after the above correction, there are still elevation-dependent vertical biases in the two DSMs. This bias can be corrected based on the relationship between the elevation 
difference and the maximum curvature over the stable terrain off of the glaciers [6,54]. After the adjustments, most of the off-glacier errors were approximately $0 \mathrm{~m}$ with a standard deviation of $0.12 \mathrm{~m}$ (Figure 3), which is an acceptable error [29].

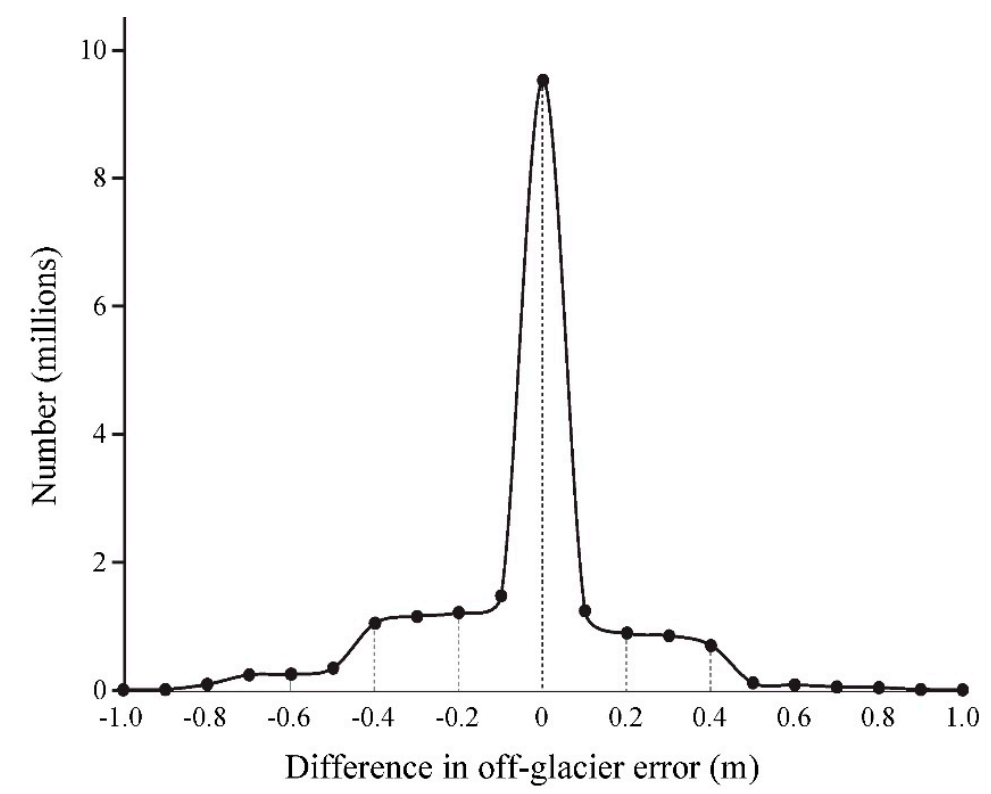

Figure 3. Final histograms of the difference in off-glacier errors.

The glacier extents in the five surveys were digitized using manual methods and adjusted images in ESRI ArcMap 10.2. The accuracy of digitizing of the glacier extent can be strongly influenced by the spatial resolution of the orthophotos [55]. We estimated the uncertainty with a pixel resolution of $0.1 \mathrm{~m}$ for the orthophotos. Approximately evenly spaced transects of clearly distinguishable surface features (70 to 80 points), i.e., primarily large boulders and small supraglacial streams, were visually selected on the orthophotos [29]. Following vector creation, a velocity surface was interpolated for the glacier using the kriging interpolation tool with a $0.47 \mathrm{~m}$ root-mean-square (RMS). The surface elevation changes were calculated using DEM differencing. A density of $850 \pm 60 \mathrm{~kg} \mathrm{~m}^{-3}$ was employed to convert ice to actual mass balance (cf. Huss, 2013).

\subsection{Mass Balance and Surface Velocity from the Glaciological Method}

There have been 22 stakes in NC01 since September 2011 (Figure 1b), which were used to measure the mass balance and surface velocity of NC01. This is called the "glaciological method" [56]. Here, they were used to validate the accuracy of the UAV results. To measure the glacier mass balance and velocity using the stakes, a pair of 5800 real-time kinematic (RTK) differential GPS (dGPS) units manufactured by Trimble Company were used. The stakes have occasionally been lost, buried under snow, or broken by ice movement, but our observation network allowed for measurements with a minimum of 15 points. The glacier mass balance for NC01 was measured following the glaciological methodology described as $b_{\mathrm{n}}=\frac{1}{S} \sum s_{i} b_{i}$, where $s_{i}$ and $b_{i}$ represent the area between the two contours and the corresponding mass balance, respectively, and $S$ is the total area of NC01 [41]. Surface velocities were measured by determining the locations of the stakes using dGPS. To compare the UAV data with the data from the stakes, we chose the time period that was consistent with the UAV surveys. The precision of the horizontal GPS measurements is approximately $0.1 \mathrm{~m}$ in glacierized areas [46]. Due to the readings and the tilt of the stakes, the mass balance at each stake has a 0.1 m uncertainty $[17,57]$. 


\section{Results}

\subsection{Glacier Terminus Retreat from 2014 to 2020}

According to UAV surveys, 5 DOMs and DSMs were obtained. After registration, the glacier boundaries were digitized by manual interpretation. The glacier extent on 19 August 2014 derived by Cao et al. [41] was also used to obtain detailed information about changes in the glacier area and terminus. The glacier terminal retreated $46.9 \pm 0.1 \mathrm{~m}$ from 2014 to 2020 , and it retreated by $22.1 \pm 0.1 \mathrm{~m}$ from 2017 to 2020 , averaging $7.4 \pm 0.1 \mathrm{~m} \mathrm{a}^{-1}$ (Table 1). The retreat rates from 2017 to $2018\left(7.7 \pm 0.1 \mathrm{~m} \mathrm{a}^{-1}\right)$ and 2018 to $2019\left(8.4 \pm 0.1 \mathrm{~m} \mathrm{a}^{-1}\right)$ were faster than those from 2019 to $2020\left(6.0 \pm 0.1 \mathrm{~m} \mathrm{a}^{-1}\right)$ (Figure 4).

Table 1. Terminus and mass balance changes of the NC01 glacier from the UAV surveys and stakes.

\begin{tabular}{|c|c|c|c|c|c|}
\hline \multirow[b]{2}{*}{ Time Interval } & \multirow[b]{2}{*}{ Days } & \multicolumn{3}{|c|}{ UAV } & \multirow{2}{*}{$\begin{array}{c}\text { Stakes } \\
\text { Mean Annual Mass } \\
\left.\text { Balance (m w.e. } a^{-1}\right)\end{array}$} \\
\hline & & Terminal Retreat (m) & $\begin{array}{l}\text { Surface Elevation } \\
\text { Change (m) }\end{array}$ & $\begin{array}{l}\text { Mean Annual Mass } \\
\left.\text { Balance (m w.e. } a^{-1}\right)\end{array}$ & \\
\hline 18 August 2017-26 August 2018 & 373 & $7.7 \pm 0.1$ & $-1.82 \pm 0.12$ & $-1.55 \pm 0.10$ & -1.57 \\
\hline 18 July 2018-26 August 2018 & 39 & $2.9 \pm 0.1$ & $-0.87 \pm 0.12$ & & \\
\hline 26 August 2018-18 August 2019 & 357 & $8.4 \pm 0.1$ & $-1.53 \pm 0.12$ & $-1.30 \pm 0.10$ & -1.27 \\
\hline 18 August 2019-13 August 2020 & 361 & $6.0 \pm 0.1$ & $-0.95 \pm 0.12$ & $-0.81 \pm 0.10$ & -0.68 \\
\hline 18 August $2017-13$ August 2020 & 3 years & $22.1 \pm 0.1$ & $-4.30 \pm 0.12$ & $-1.22 \pm 0.10$ & -1.17 \\
\hline
\end{tabular}
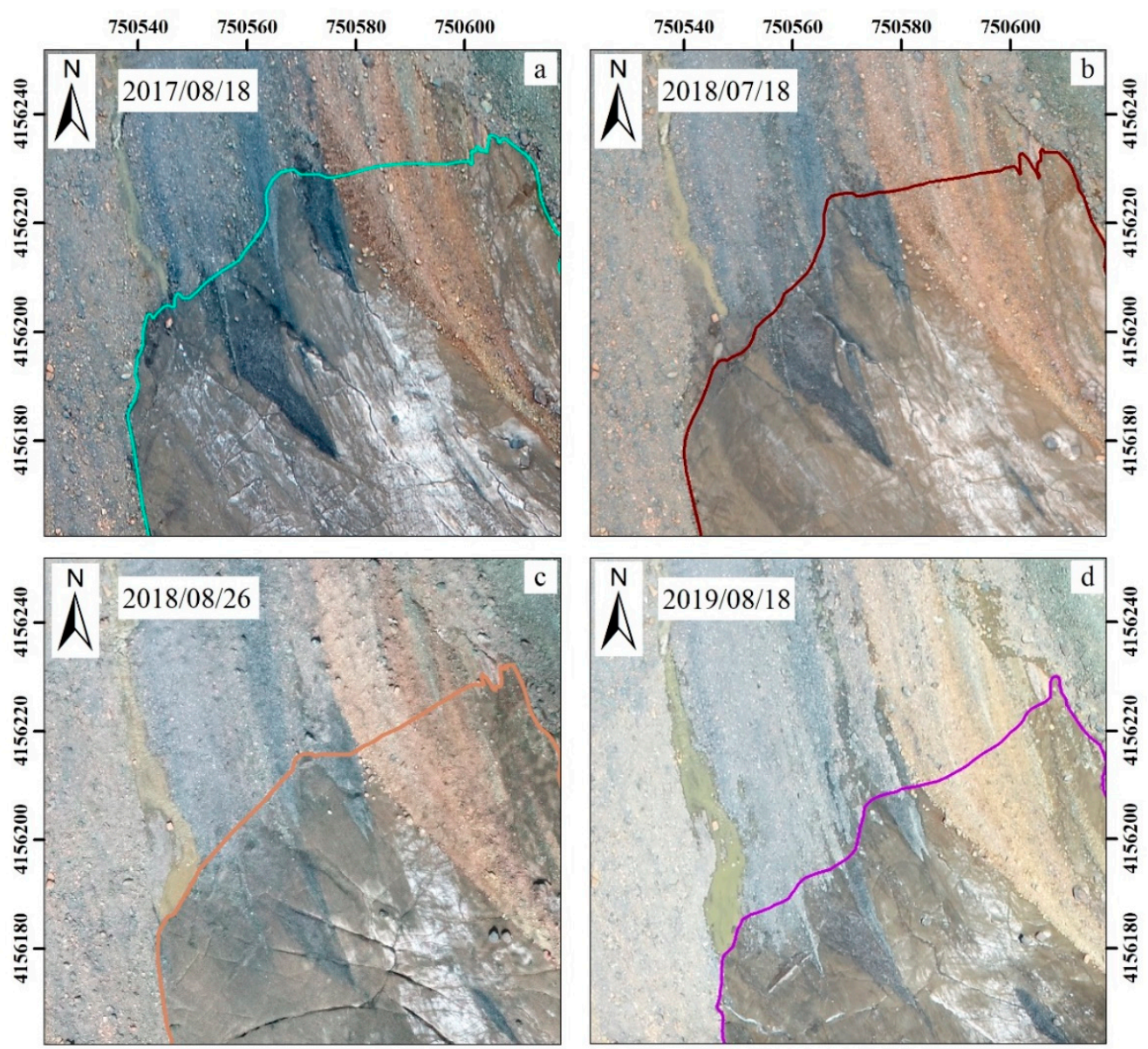

Figure 4. Cont. 

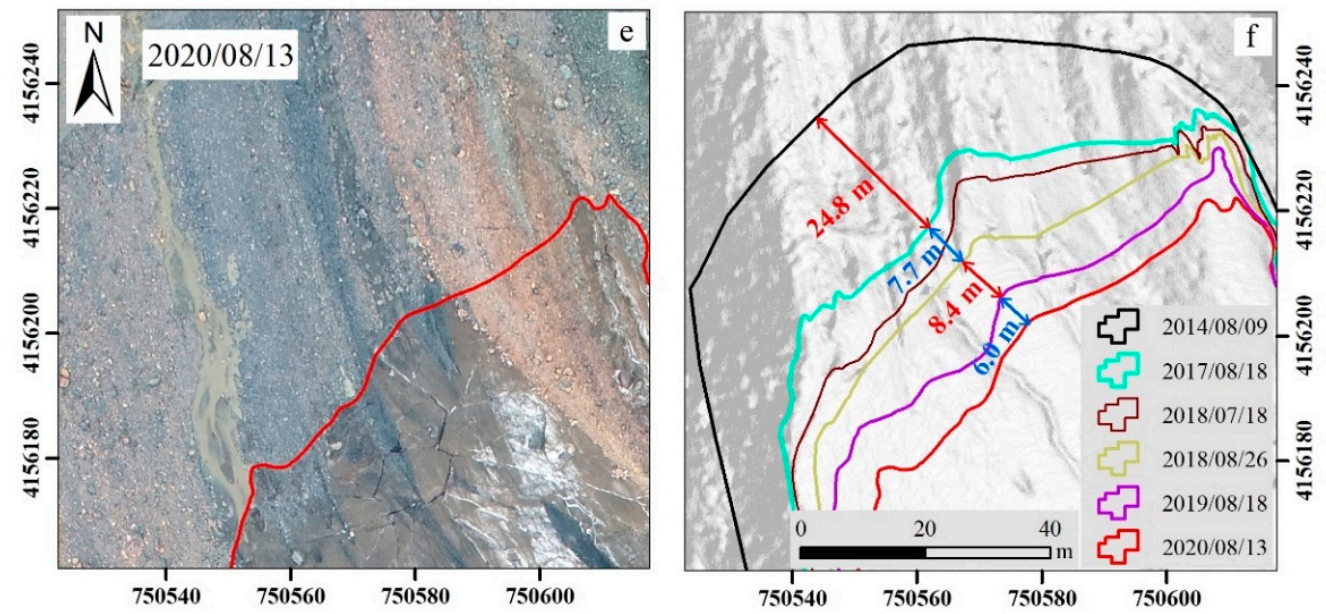

Figure 4. (a-e) DOMs and glacier outlines in glacier terminus from UAVs at different times. (f) Terminus retreat from 2014 to 2020.

\subsection{Glacier Surface Elevation Change and Velocity}

Though DEM differencing was generated by the UAV data, changes in the surface elevation were highly variable across NC01, including areas of both loss and gain (Figure 5). The surface elevation change was $-4.30 \pm 0.12 \mathrm{~m}$ in the period of 18 August 201726 August 2020, with a mean annual mass balance of $-1.22 \pm 0.10 \mathrm{~m}$ w.e. The rate of glacier thinning varied from region to region on the surface of the glacier. On the whole, the rate of glacier thinning was more dramatic in the lower part of the glacier and slightly slower in the upper part of the glacier (Figure 6a), which was mainly controlled by temperature; the lower the altitude was, the higher the positive accumulated temperature, and the stronger the ablation.

Similar to the terminus change, the negative mass balances from 2017 to 2018 $(-1.55 \pm 0.10 \mathrm{~m}$ w.e. $)$ and 2018 to $2019(-1.30 \mathrm{~m}$ w.e. $)$ were stronger than those from 2019 to 2020 ( $-0.81 \mathrm{~m}$ w.e.) (Figure 5; Table 1). In addition, glacier thinning in the 39 days of the ablation season accounted for $47.8 \%$ of the thinning in the annual interval of 2017-2018 (Figure 6b). The surface elevation changes were $-0.87 \pm 0.12 \mathrm{~m}$ and $-1.82 \pm 0.12 \mathrm{~m}$ in the periods of 18 August 2018-26 August 2018 and 18 August 201726 August 2018, respectively.

Due to the absence of any clearly distinguishable surface features in the upper part of the glacier, we only obtained velocities under $300 \mathrm{~m}$ from the summit of NC01. The results showed that the mean surface velocity for NC01 was $1.21 \pm 0.47 \mathrm{~m}$ and $1.79 \pm 0.47 \mathrm{~m}$ from 18 August 2017-26 August 2018 and 18 August 2017-26 August 2018, respectively (Figure 7). The mean displacement that occurred in the 39-day interval accounted for $67.6 \%$ of the total annual displacement. In general, the surface velocity along the glacier flowline increased gradually from the upstream to the central region, reached its maximum, and then decreased gradually to the terminal edge [58,59]. According to the velocities we obtained from 18 July 2018-26 August 2018 and 18 August 2017-26 August 2018, the velocity distribution pattern of NC01 is generally consistent with the general pattern (Figure 6c). 


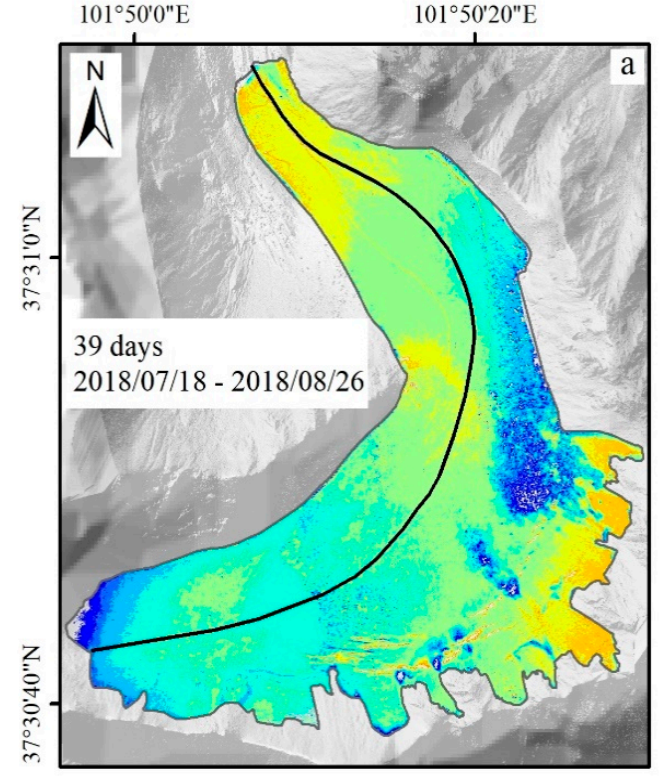

$101^{\circ} 50^{\prime} 0^{\prime \prime} \mathrm{E}-101^{\circ} 50^{\prime} 20^{\prime \prime} \mathrm{E}$
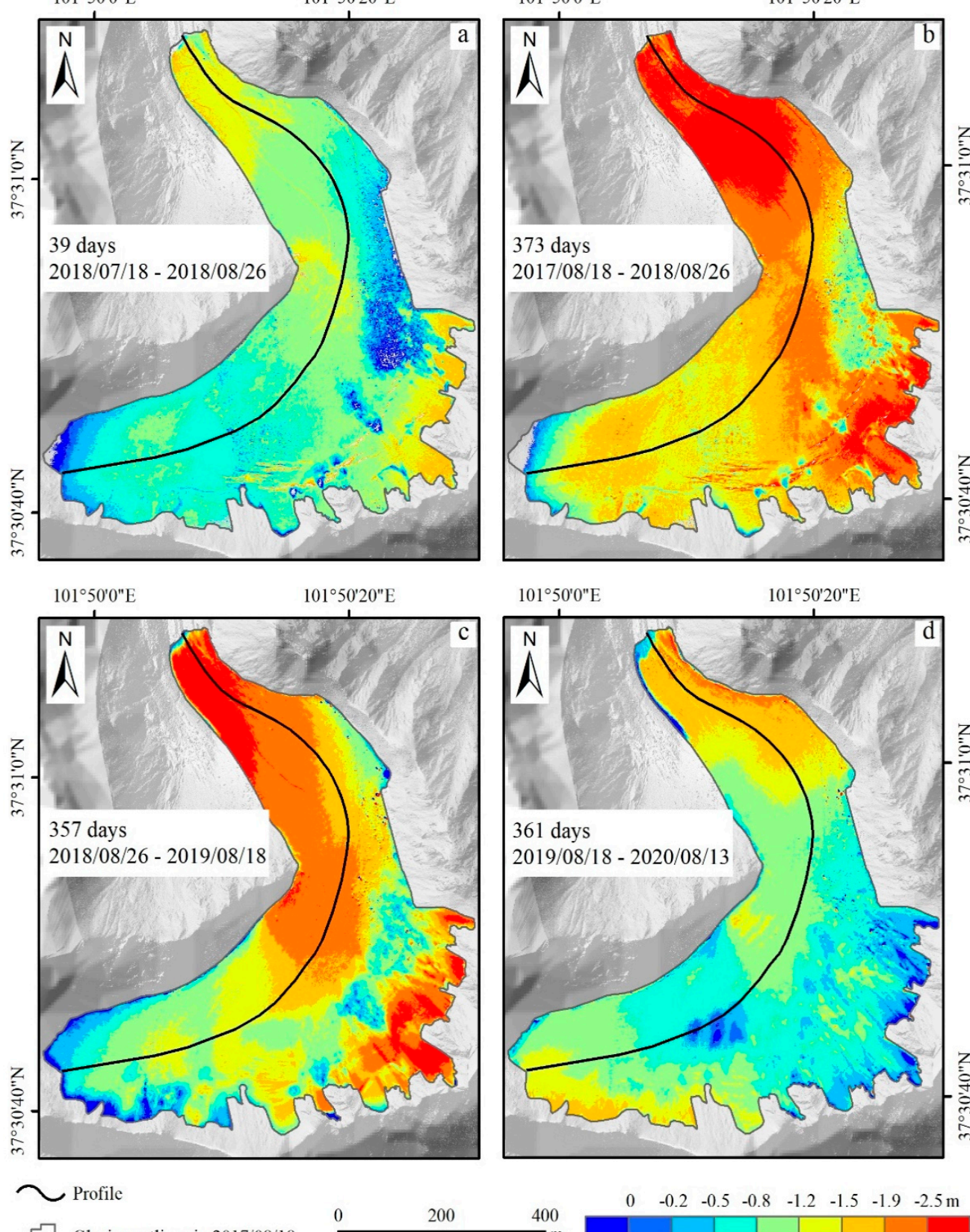

$101^{\circ} 50^{\prime} 0 " \mathrm{E} \quad 101^{\circ} 50^{\prime} 20^{\prime \prime} \mathrm{E}$

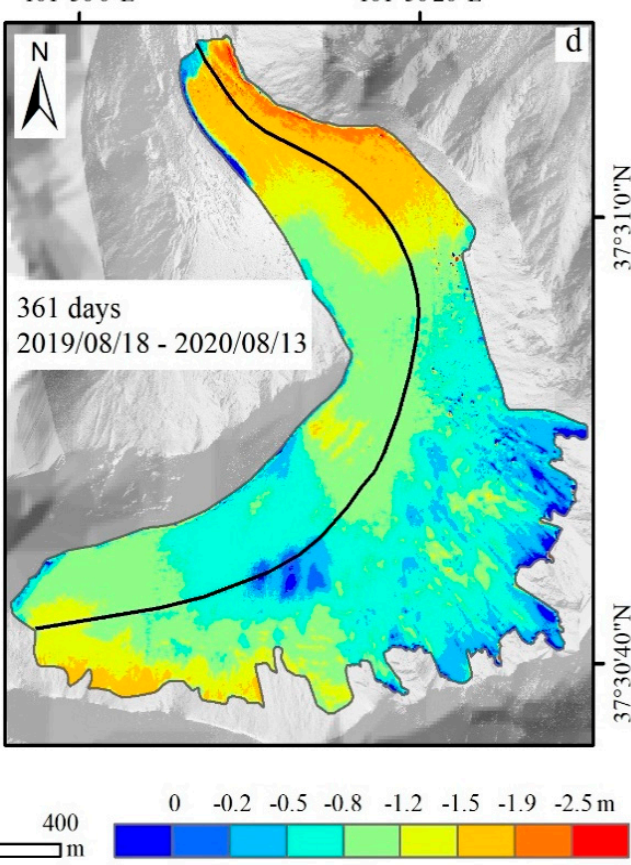

Figure 5. Glacial surface elevation changes in NC01 during different periods from 2017 to 2020. 


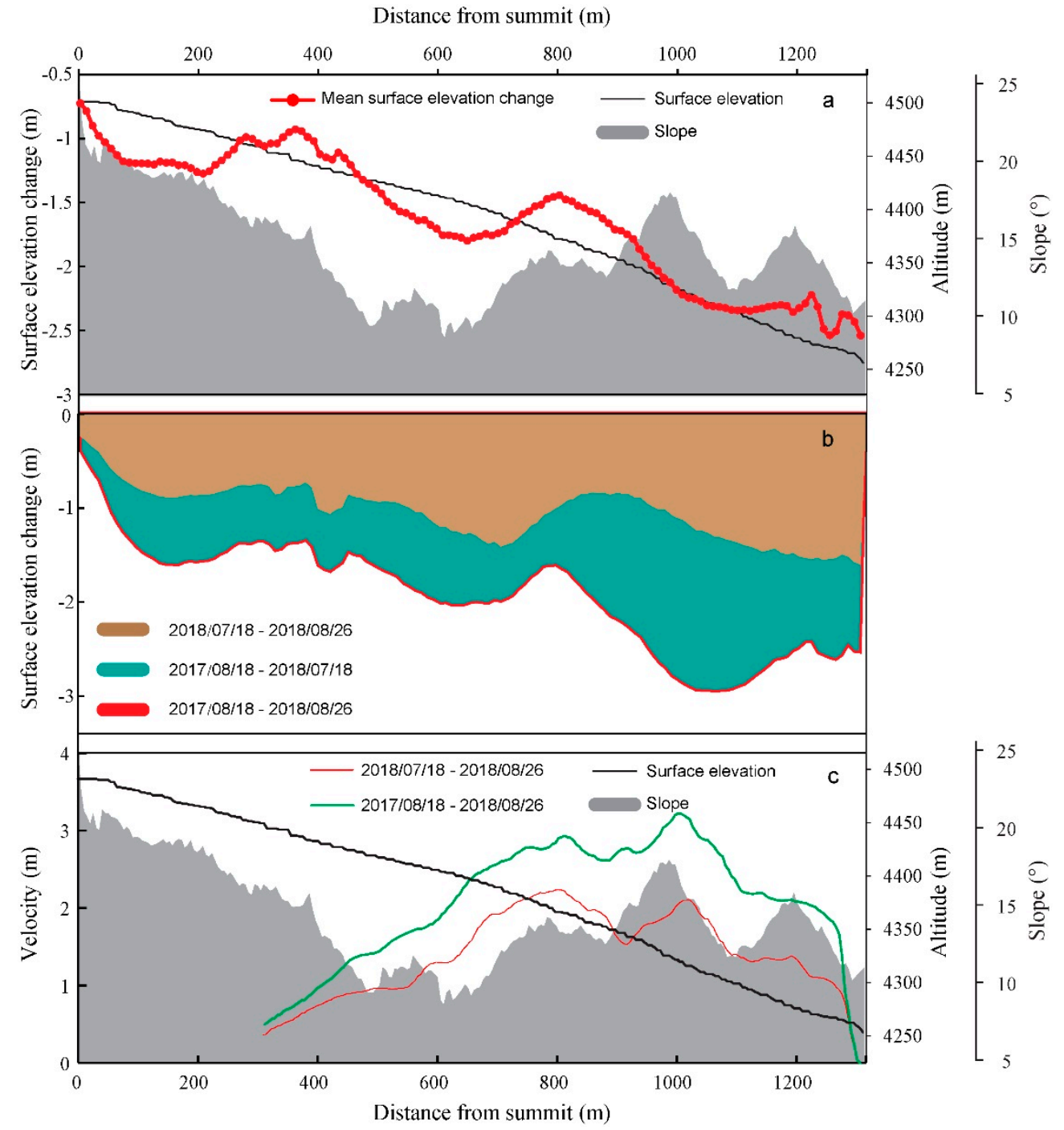

Figure 6. (a) Transect of the profile in Figure 5 displaying the altitude (black), slope (gray), and mean surface elevation change over 3 years (18 August 2017-13 August 2020, red). (b) Surface elevation changes over 39 days (18 August 2018-26 August 2018, brown), 11 months (18 August 201718 July 2018, green), and 1 year (18 August 2017 to 26 August 2018, red). (c) Transect of the profile in Figure 7, displaying the altitude (black), slope (gray), and velocity over 39 days (18 July 201818 August 2018, red) and 1 year (18 August 2017-26 August 2018, green). 

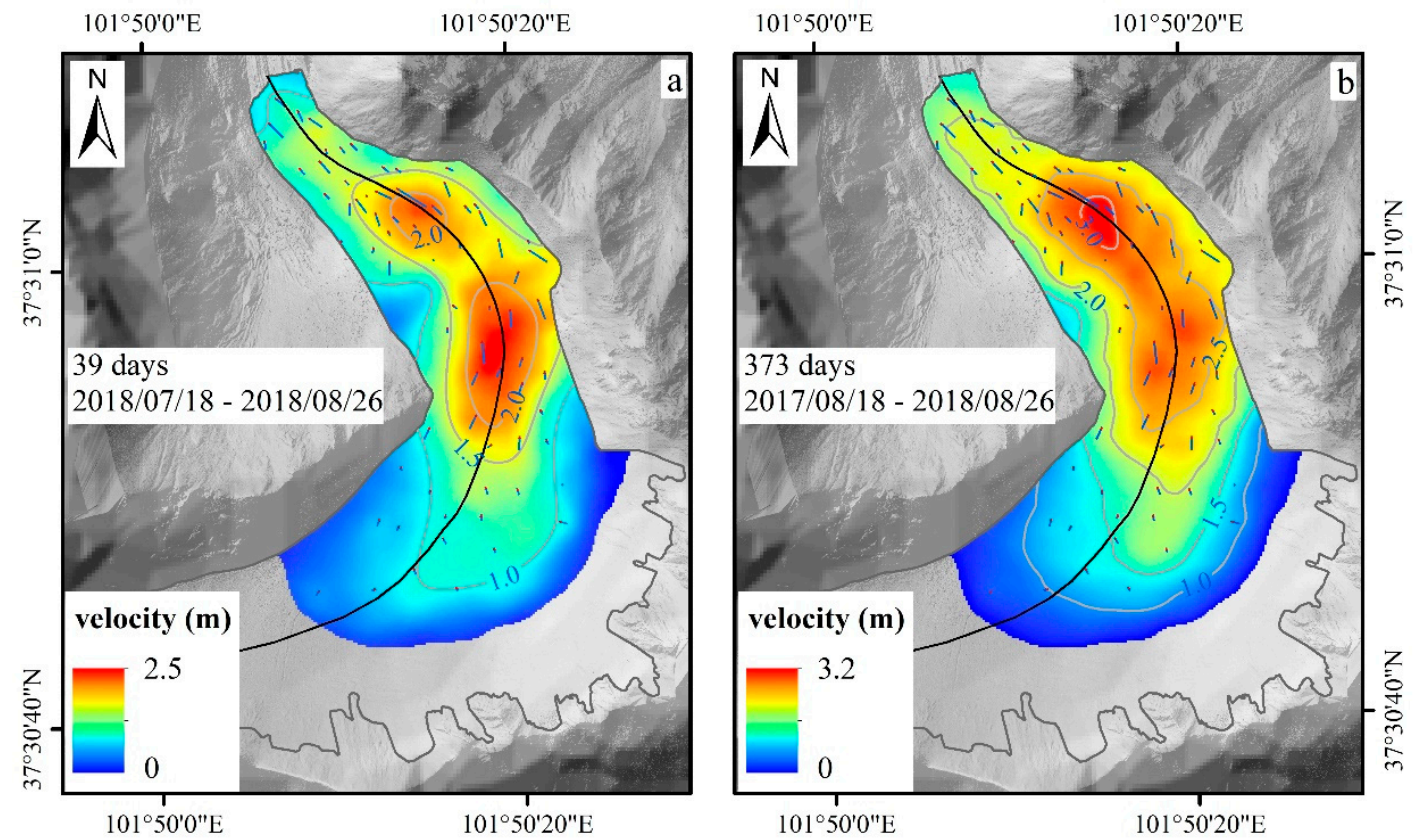

Figure 7. Glacial surface velocity of NC01 from 18 July 2018 to 26 August 2018 (a) and from 18 August 2017 to 26 August 2018 (b).

\section{Discussion}

\subsection{Comparison of the Results of the UAV and Glaciological Method}

Strictly speaking, the mass balance obtained by the glaciological method and the geodetic method are different. The former measures the surface mass balance [60], whereas the latter measures glacier elevation changes and mainly include surface mass balance and vertical velocity [58]. Vertical velocity refers to the upward or downward flow of the ice relative to the glacier surface at a fixed coordinate, and it is called "emergence velocity" in the ablation area and "submergence velocity" in the accumulation area [58]. The emergence and submergence velocity will have a certain influence on the dynamic process [61]. Dehecq et al. [62] pointed out that with continuous glacier loss and the decrease of accumulation area ratio (AAR), emergence velocity will gradually decrease. For example, this phenomenon has been observed in both the Lirung Glacier [63] in the Nepal Himalayas and the Qiyi Glacier in Qilian Mountains [64].

By comparing the stake ablation data and the surface elevation changes from the DSM differencing results, we found that in most stake positions, the two results corresponded very well, with an absolute difference of less than $0.3 \mathrm{~m}$ w.e. (Figure $8 \mathrm{a}$ ). Due to the small size (less than $0.5 \mathrm{~km}^{2}$ ), the slower surface velocity (less than $3.2 \mathrm{~m} \mathrm{a}^{-1}$ ), and the ELA exceeding the maximum height of the glacier [41], the emergence velocity of the NC01 glacier should be very small. It is difficult to determine this by the difference between the glacier mass balance and the surface elevation change, because this value itself is within the error range. Therefore, the influence of emergence velocity on the results has been neglected. There is a considerable difference between only one stake ablation value and the DSM difference, mainly because that stake is located in an area with a relatively large slope. During the observation of this stake, the ablation was slightly overestimated.

The absolute difference between the velocity after interpolation through the feature points and the GPS measurements in stake positions is within $1 \mathrm{~m}$. Compared to the precision of the surface elevation change, the precision of the velocity is slightly lower, which may be because it was obtained indirectly through interpolation, where some uncertainty was generated. Similarly, one stake displacement value does not correspond to the interpolation results of the feature points (Figure $8 \mathrm{~b}$ ). The main reason is that the feature points in the upper part of the glacier are relatively sparse, which leads to the interpolation results underestimating the velocity in some areas. The findings reveal that 
UAVs have a very high accuracy in glacier mass balance research and a relatively high accuracy in velocity research.
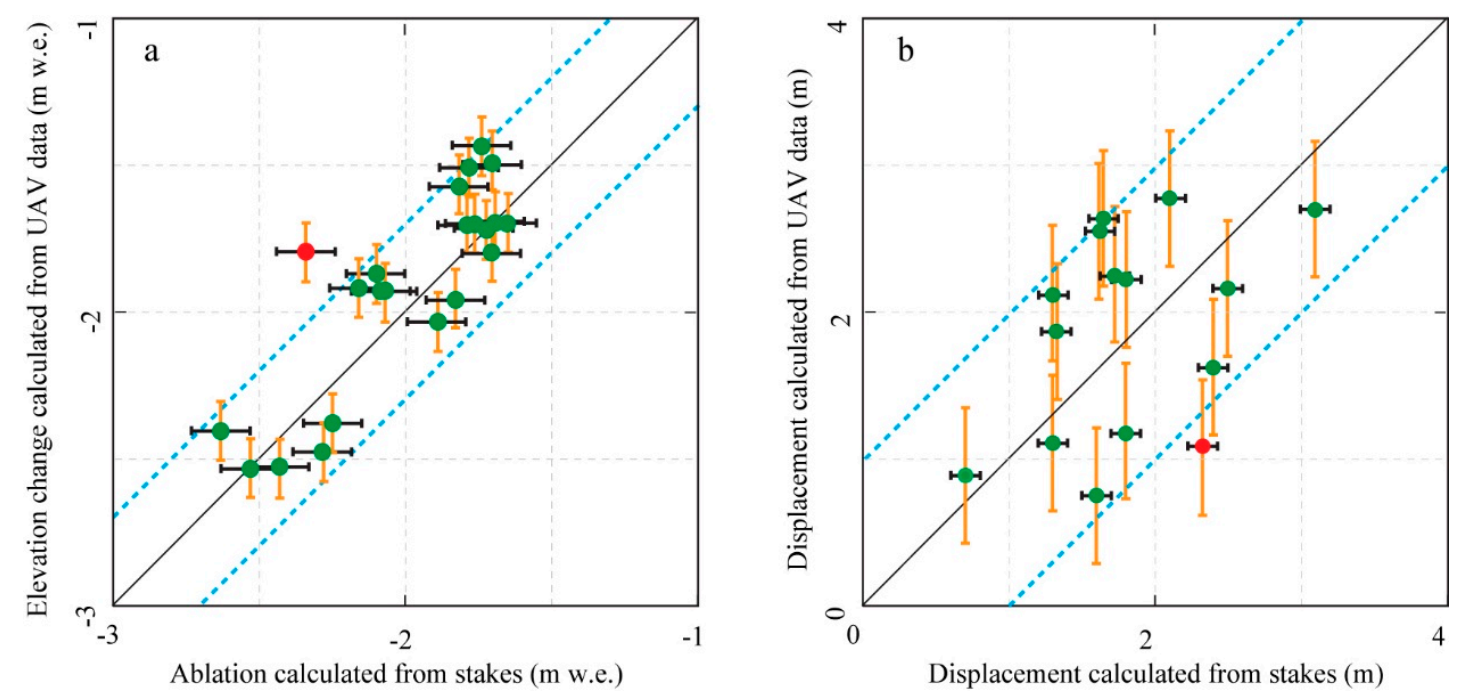

Figure 8. Observations acquired using the stakes compared to the results obtained by the UAVs. (a) The ablation quantified from the stakes vs. the surface elevation change obtained from the DSM difference of the UAV surveys with $0.1 \mathrm{~m}$ error bars for both variables. The dotted blue line represents a $0.3 \mathrm{~m}$ w.e. error line. (b) The displacement calculated from the stakes vs. the displacement obtained from the UAV surveys with error bars $0.05 \mathrm{~m}$ and $0.47 \mathrm{~m}$, respectively. The dotted blue line represents a $1.0 \mathrm{~m}$ error line.

\subsection{Factors Influencing Glacier Changes}

Pan et al. [40] and Cao et al. [41,43,46] documented that glacier shrinkage in this study area can probably be attributed to the increase in air temperature. According to the datasets recorded at the Menyuan meteorological station (2924 m asl) located $20 \mathrm{~km}$ away from the NC01 glacier, the summer (JJA) air temperatures in 2018, 2019, and 2020 were $14.0^{\circ} \mathrm{C}$, $12.4^{\circ} \mathrm{C}$, and $12.2^{\circ} \mathrm{C}$, respectively, which were significantly higher than the mean values from 1972-2010 [46]. This partly explains the dramatic glacier terminus retreat and negative mass balance from 2017 to 2019.

As the air temperature is the main factor controlling glacier melting and the air temperature is related to the altitude, there is an obvious correlation between the mean glacier surface elevation change and altitude (Figure 6a), with the exception of a location that is approximately $400-800 \mathrm{~m}$ from the summit. This may be because the slope here is less steep and more radiation is received; hence, melting is stronger. In addition, the same pattern is observed for surface elevation changes during the period of 18 August 201726 August 2018 (Figure 6b). However, according to the characteristics of the 39-day interval (18 August 2018-26 August 2018) melt, melting was strong in the entire glacier area, which was related to the altitude but was not obvious. It may be that the summer temperature is so high $\left(14.7^{\circ} \mathrm{C}\right.$ at Menyuan station) that the entire ice surface was in a state of intense melting, which also led to a large amount of melting during the aforementioned year (18 August 2017-26 August 2018) (Figure 6b).

The velocity along the flowline increased gradually from the upstream region to the central region and reached its maximum value at a location $800 \mathrm{~m}$ from the summit. However, a second peak appeared in the lower part of the glacier, about $1000 \mathrm{~m}$ from the summit. Cao et al. [65] also found that the maximum glacier velocity occurred in the lower location. There are two possible reasons for this occurrence: the slope is steeper (Figure 6c), and the glaciers are thicker [41] at this location. According to Glen's flow law, the surface velocity is positively related to slope and thickness [58], which may be the reason for the high velocity in this area. 


\subsection{Comparison with Previous Results}

A comparison with previous results showed that the retreat rate at the terminus of the glacier showed late acceleration (Table 2). The rate of terminal retreat has gradually increased from $4.0 \mathrm{~m} \mathrm{a}^{-1}$ in 1972-1995 to $7.4 \pm 0.1 \mathrm{~m} \mathrm{a}^{-1}$ at present. Moreover, the mass balance of the glacier also became more negative, changing from $-0.7 \mathrm{~m}$ w.e. $\mathrm{a}^{-1}$ in 1972-2010 to $-1.22 \pm 0.10 \mathrm{~m}$ w.e. $\mathrm{a}^{-1}$ at present. As climate change continues to accelerate, glaciers will continue to retreat at an accelerating rate. The same phenomenon occurs for many glaciers, such as in the Tien Shan, the Nyainqentanglha Mountains, and the Himalayas [66-69]. However, glacier velocity showed a decreasing trend; whether measured using stakes or interpolation from distinguishable surface features, the maximum speed of the glacier from 2010 to 2012 was $4.0 \mathrm{~m} \mathrm{a}^{-1}$ [65], while from 2017 to 2018 , the maximum speed of the glacier was only $3.2 \pm 0.47 \mathrm{~m} \mathrm{a}^{-1}$. Dehecq et al. [62] compared the velocity to the mass balance of many glaciers in High Mountain Asia and found that in most regions, glacier velocity tended to slow and suggested that changes in velocity can be explained by changes in gravity driving stress, which are largely controlled by changes in ice thickness. Therefore, the slowing of glacier NC01 may also be due to continuous negative balance.

Table 2. Changes in glacier characteristics compared with those from previous studies of NC01.

\begin{tabular}{cccc}
\hline Glacier Characteristics & Time Interval & Rate & Reference \\
\hline \multirow{3}{*}{ Terminal retreat rate } & $1972-1995$ & $4.0 \mathrm{~m} \mathrm{a}^{-1}$ & {$[46]$} \\
& $1995-2010$ & $5.3 \mathrm{~m} \mathrm{a}^{-1}$ & {$[46]$} \\
& $2017-2020$ & $7.4 \mathrm{~m} \mathrm{a}^{-1}$ & This research \\
\hline \multirow{2}{*}{ Mass balance } & $1972-2010$ & $-0.7 \mathrm{~m} \mathrm{w.e.}^{-1}$ & {$[46]$} \\
& $2010-2015$ & $-0.9 \mathrm{~m} \mathrm{w.e.}^{-1}$ & {$[41]$} \\
& $2017-2020$ & $-1.22 \pm 0.10 \mathrm{~m} \mathrm{w}$ w. a $^{-1}$ & This research \\
\hline \multirow{2}{*}{ Maximum velocity } & $2010-2012$ & $4.0 \mathrm{~m} \mathrm{a}^{-1}$ & {$[46]$} \\
& $2010-2015$ & $3.6 \pm 0.05 \mathrm{~m} \mathrm{a}^{-1}$ & {$[41]$} \\
& $2017-2018$ & $3.2 \pm 0.47 \mathrm{~m} \mathrm{a}^{-1}$ & This research \\
\hline
\end{tabular}

\section{Conclusions}

UAV surveys were conducted to reconstruct a glacier surface with accuracies higher than those previously reported using satellite images, allowing for small changes to be measured. Through five surveys over the NC01 glacier, we obtained detailed glacier characteristics for the past 3 years, including the retreat of the glacier terminal edge, the change in the glacier surface elevation, and the glacier velocity. The results show that the glacier terminal retreat was $7.4 \pm 0.1 \mathrm{~m} \mathrm{a}^{-1}$, the annual mass balance was $-1.22 \pm 0.1 \mathrm{~m}$ w.e. from 2017 to 2020, and the maximum velocity of the glacier was $3.2 \pm 0.47 \mathrm{~m}$ from 2017 to 2018. These data were validated through independent stakes measurements, which clearly showed the consistency of the results. Glacial thinning in the 39 days of the ablation season accounted for $47.8 \%$ of the thinning in the annual interval. The displacement occurring in the 39 days of the ablation season accounted for $67.6 \%$ of the total displacement. This implies that glacier melting and velocity in the summer are very intense. In addition, a comparison with previous results revealed that the retreat of the terminal edge and thinning of the glacier showed a trend of late acceleration, while the glacier velocity slowed as the glacier thinned.

Author Contributions: Conceptualization, B.C. and W.G.; methodology, W.G.; software, W.G.; validation, B.C., K.L. and X.S.; formal analysis, B.P.; investigation, B.C.; resources, B.P.; data curation, W.G.; writing—original draft preparation, B.C.; writing—review and editing, W.G.; visualization, W.G.; supervision, B.P.; project administration, B.C.; funding acquisition, B.C. All authors have read and agreed to the published version of the manuscript. 
Funding: This research was funded by the Second Tibetan Plateau Scientific Expedition and Research Program (STEP, grant no. 2019QZKK0205), National Natural Science Foundation of China (grant no. 42071077), and Fundamental Research Funds for the Central Universities (lzujbky-2021-kb12) and The APC was funded by the Second Tibetan Plateau Scientific Expedition and Research Program (STEP, grant no. 2019QZKK0205).

Institutional Review Board Statement: Not applicable.

Informed Consent Statement: Not applicable.

Data Availability Statement: Data are available upon request by email to the corresponding author.

Conflicts of Interest: The authors declare no conflict of interest.

\section{References}

1. IPCC. Climate Change 2013, The Physical Science Basis, Working Group I Contribution to the Fifth Assessment Report of the Intergovernmental Panel on Climate Change; WMO/UNEP, Cambridge University Press: Geneva, Switzerland, 2013.

2. Immerzeel, W.W.; van Beek, L.P.H.; Bierkens, M.F.P. Climate Change Will Affect the Asian Water Towers. Science 2010, 328, 1382-1385. [CrossRef] [PubMed]

3. Immerzeel, W.W.; Pellicciotti, F.; Bierkens, M.F.P. Rising river flows throughout the twenty-first century in two Himalayan glacierized watersheds. Nat. Geosci. 2013, 6, 742-745. [CrossRef]

4. Pritchard, H.D. Asia's shrinking glaciers protect large populations from drought stress. Nature 2019, 569, 649-654. [CrossRef]

5. Bolch, T.; Kulkarni, A.; Kääb, A.; Huggel, C.; Paul, F.; Cogley, J.G.; Frey, H.; Kargel, J.S.; Fujita, K.; Scheel, M.; et al. The State and Fate of Himalayan Glaciers. Science 2012, 336, 310-314. [CrossRef]

6. Gardelle, J.; Berthier, E.; Arnaud, Y. Slight mass gain of Karakoram glaciers in the early twenty-first century. Nat. Geosci. 2012, 5, 322-325. [CrossRef]

7. Kääb, A.; Berthier, E.; Nuth, C.; Gardelle, J.; Arnaud, Y. Contrasting patterns of early twenty-first-century glacier mass change in the Himalayas. Nature 2012, 488, 495-498. [CrossRef]

8. Brun, F.; Berthier, E.; Wagnon, P.; Kääb, A.; Treichler, D. A spatially resolved estimate of High Mountain Asia glacier mass balances from 2000 to 2016. Nat. Geosci. 2017, 10, 668. [CrossRef]

9. Shea, J.M.; Immerzeel, W.W.; Wagnon, P.; Vincent, C.; Bajracharya, S. Modelling glacier change in the Everest region, Nepal Himalaya. Cryosphere 2015, 9, 1105-1128. [CrossRef]

10. Hock, R.; Bliss, A.; Marzeion, B.E.N.; Giesen, R.H.; Hirabayashi, Y.; Huss, M.; RadiĆ, V.; Slangen, A.B.A. GlacierMIP-A model intercomparison of global-scale glacier mass-balance models and projections. J. Glaciol. 2019, 65, 453-467. [CrossRef]

11. Paul, F.; Bolch, T.; Kääb, A.; Nagler, T.; Nuth, C.; Scharrer, K.; Shepherd, A.; Strozzi, T.; Ticconi, F.; Bhambri, R.; et al. The glaciers climate change initiative: Methods for creating glacier area, elevation change and velocity products. Remote Sens. Environ. 2015, 162, 408-426. [CrossRef]

12. Bahr, D.B.; Radić, V. Significant contribution to total mass from very small glaciers. Cryosphere 2012, 6, 763-770. [CrossRef]

13. Hoinkes, H. Methoden und Möglichkeiten von Massenhaushaltsstudien auf Gletschern. Z. Für Gletsch. Und Glazialgeol. 1970, 6, 37-90.

14. Ye, Q.; Bolch, T.; Naruse, R.; Wang, Y.; Zong, J.; Wang, Z.; Zhao, R.; Yang, D.; Kang, S. Glacier mass changes in Rongbuk catchment on Mt. Qomolangma from 1974 to 2006 based on topographic maps and ALOS PRISM data. J. Hydrol. 2015, 530, 273-280. [CrossRef]

15. Gao, J.; Liu, Y. Applications of remote sensing, GIS and GPS in glaciology: A review. Prog. Phys. Geogr. Earth Environ. 2001, 25, 520-540. [CrossRef]

16. Leprince, S.; Barbot, S.; Ayoub, F.; Avouac, J.-P. Automatic and Precise Orthorectification, Coregistration, and Subpixel Correlation of Satellite Images, Application to Ground Deformation Measurements. IEEE Trans. Geosci. Remote Sens. 2007, 45, 1529-1558. [CrossRef]

17. Bash, E.; Moorman, B.; Gunther, A. Detecting Short-Term Surface Melt on an Arctic Glacier Using UAV Surveys. Remote Sens. 2018, 10, 1547. [CrossRef]

18. Pętlicki, M.; Sziło, J.; MacDonell, S.; Vivero, S.; Bialik, R.J. Recent Deceleration of the Ice Elevation Change of Ecology Glacier (King George Island, Antarctica). Remote Sens. 2017, 9, 520. [CrossRef]

19. Xu, C.; Li, Z.; Wang, F.; Mu, J. Spatio-Temporal Changes of Mass Balance in the Ablation Area of the Muz Taw Glacier, Sawir Mountains, from Multi-Temporal Terrestrial Geodetic Surveys. Remote Sens. 2021, 13, 1465. [CrossRef]

20. Petlicki, M. Subglacial Topography of an Icefall Inferred From Repeated Terrestrial Laser Scanning. IEEE Geosci. Remote Sens. Lett. 2018, 15, 1461-1465. [CrossRef]

21. Podgórski, J.; Pętlicki, M. Detailed Lacustrine Calving Iceberg Inventory from Very High Resolution Optical Imagery and Object-Based Image Analysis. Remote Sens. 2020, 12, 1807. [CrossRef]

22. Pellicciotti, F.; Brock, B.; Strasser, U.; Burlando, P.; Funk, M.; Corripio, J. An enhanced temperature-index glacier melt model including the shortwave radiation balance: Development and testing for Haut Glacier d'Arolla, Switzerland. J. Glaciol. 2005, 51, 573-587. [CrossRef] 
23. Śledź, S.; Ewertowski, M.W.; Piekarczyk, J. Applications of unmanned aerial vehicle (UAV) surveys and Structure from Motion photogrammetry in glacial and periglacial geomorphology. Geomorphology 2021, 378, 107620. [CrossRef]

24. Scherler, D.; Leprince, S.; Strecker, M.R. Glacier-surface velocities in alpine terrain from optical satellite imagery-Accuracy improvement and quality assessment. Remote Sens. Environ. 2008, 112, 3806-3819. [CrossRef]

25. Joughin, I.; Smith, B.E.; Shean, D.E.; Floricioiu, D. Brief Communication: Further summer speedup of Jakobshavn Isbræ. Cryosphere 2014, 8, 209-214. [CrossRef]

26. Colomina, I.; Molina, P. Unmanned aerial systems for photogrammetry and remote sensing: A review. ISPRS J. Photogramm. Remote Sens. 2014, 92, 79-97. [CrossRef]

27. Chandler, B.M.P.; Lovell, H.; Boston, C.M.; Lukas, S.; Barr, I.D.; Benediktsson, Í.Ö.; Benn, D.I.; Clark, C.D.; Darvill, C.M.; Evans, D.J.A.; et al. Glacial geomorphological mapping: A review of approaches and frameworks for best practice. Earth-Sci. Rev. 2018, 185, 806-846. [CrossRef]

28. Bhardwaj, A.; Sam, L.; Akanksha; Martín-Torres, F.J.; Kumar, R. UAVs as remote sensing platform in glaciology: Present applications and future prospects. Remote Sens. Environ. 2016, 175, 196-204. [CrossRef]

29. Immerzeel, W.W.; Kraaijenbrink, P.D.A.; Shea, J.M.; Shrestha, A.B.; Pellicciotti, F.; Bierkens, M.F.P.; de Jong, S.M. High-resolution monitoring of Himalayan glacier dynamics using unmanned aerial vehicles. Remote Sens. Environ. 2014, 150, 93-103. [CrossRef]

30. Kraaijenbrink, P.D.A.; Shea, J.M.; Pellicciotti, F.; Jong, S.M.d.; Immerzeel, W.W. Object-based analysis of unmanned aerial vehicle imagery to map and characterise surface features on a debris-covered glacier. Remote Sens. Environ. 2016, 186, 581-595. [CrossRef]

31. Ryan, J.C.; Hubbard, A.L.; Box, J.E.; Todd, J.; Christoffersen, P.; Carr, J.R.; Holt, T.O.; Snooke, N. UAV photogrammetry and structure from motion to assess calving dynamics at Store Glacier, a large outlet draining the Greenland ice sheet. Cryosphere 2015, 9, 1-11. [CrossRef]

32. Westoby, M.J.; Brasington, J.; Glasser, N.F.; Hambrey, M.J.; Reynolds, J.M. 'Structure-from-Motion' photogrammetry: A low-cost, effective tool for geoscience applications. Geomorphology 2012, 179, 300-314. [CrossRef]

33. Wigmore, O.; Mark, B. Monitoring tropical debris-covered glacier dynamics from high-resolution unmanned aerial vehicle photogrammetry, Cordillera Blanca, Peru. Cryosphere 2017, 11, 2463-2480. [CrossRef]

34. Rossini, M.; Di Mauro, B.; Garzonio, R.; Baccolo, G.; Cavallini, G.; Mattavelli, M.; De Amicis, M.; Colombo, R. Rapid melting dynamics of an alpine glacier with repeated UAV photogrammetry. Geomorphology 2018, 304, 159-172. [CrossRef]

35. Fugazza, D.; Scaioni, M.; Corti, M.; D'Agata, C.; Azzoni, R.S.; Cernuschi, M.; Smiraglia, C.; Diolaiuti, G.A. Combination of UAV and terrestrial photogrammetry to assess rapid glacier evolution and map glacier hazards. Nat. Hazards Earth Syst. Sci. 2018, 18, 1055-1071. [CrossRef]

36. Dall'Asta, E.; Forlani, G.; Roncella, R.; Santise, M.; Diotri, F.; Morra di Cella, U. Unmanned Aerial Systems and DSM matching for rock glacier monitoring. ISPRS J. Photogramm. Remote Sens. 2017, 127, 102-114. [CrossRef]

37. Xue, Y.; Jing, Z.; Kang, S.; He, X.; Li, C. Combining UAV and Landsat data to assess glacier changes on the central Tibetan Plateau. J. Glaciol. 2021, 1-13. [CrossRef]

38. Chandler, B.M.P.; Evans, D.J.A.; Chandler, S.J.P.; Ewertowski, M.W.; Lovell, H.; Roberts, D.H.; Schaefer, M.; Tomczyk, A.M. The glacial landsystem of Fjallsjökull, Iceland: Spatial and temporal evolution of process-form regimes at an active temperate glacier. Geomorphology 2020, 361, 107192. [CrossRef]

39. Shangguan, D.; Liu, S.; Ding, Y.; Zhang, Y.; Li, J.; Li, X.; Wu, Z. Changes in the elevation and extent of two glaciers along the Yanglonghe river, Qilian Shan, China. J. Glaciol. 2010, 56, 309-317. [CrossRef]

40. Pan, B.; Cao, B.; Wang, J.; Zhang, G.; Zhang, C.; Hu, Z.; Huang, B. Glacier variations in response to climate change from 1972 to 2007 in the western Lenglongling mountains, northeastern Tibetan Plateau. J. Glaciol. 2012, 58, 879-888. [CrossRef]

41. Cao, B.; Pan, B.; Guan, W.; Wang, J.; Wen, Z. Changes in ice volume of the Ningchan No.1 Glacier, China, from 1972 to 2014 , as derived from in situ measurements. J. Glaciol. 2017, 63, 1025-1033. [CrossRef]

42. Cao, B.; Pan, B.; Cai, M.; Wang, J. An investigation on changes in glacier mass balance and hypsometry for a small mountainous glacier in the northeastern Tibetan Plateau. J. Mt. Sci. 2017, 14, 1624-1632. [CrossRef]

43. Cao, B.; Pan, B.; Wen, Z.; Guan, W.; Li, K. Changes in glacier mass in the Lenglongling Mountains from 1972 to 2016 based on remote sensing data and modeling. J. Hydrol. 2019, 578, 124010. [CrossRef]

44. Tian, H.; Yang, T.; Liu, Q. Climate change and glacier area shrinkage in the Qilian mountains, China, from 1956 to 2010. Ann. Glaciol. 2014, 55, 187-197. [CrossRef]

45. Wang, Z.; Liu, C.; You, G.; Pu, J.; Yang, H.; Tian, P. Glacier Inventory of China I Qilian Mountains; Science Press Academia Sinica, Lanzhou Institute of Glaciology and Cryopedology: Beijing, China, 1981. (In Chinese)

46. Cao, B.; Pan, B.; Wang, J.; Shangguan, D.; Wen, Z.; Qi, W.; Cui, H.; Lu, Y. Changes in the glacier extent and surface elevation along the Ningchan and Shuiguan river source, eastern Qilian Mountains, China. Quat. Res. 2014, 81, 531-537. [CrossRef]

47. Agisoft PhotoScan User Manual: Professional Edition, Version 1.2; Agisoft LLC.: St. Petersburg, Russia, 2016.

48. Verhoeven, G. Taking computer vision aloft-archaeological three-dimensional reconstructions from aerial photographs with photoscan. Archaeol. Prospect. 2011, 18, 67-73. [CrossRef]

49. Kraaijenbrink, P.; Meijer, S.W.; Shea, J.M.; Pellicciotti, F.; Jong, S.M.D.; Immerzeel, W.W. Seasonal surface velocities of a Himalayan glacier derived by automated correlation of unmanned aerial vehicle imagery. Ann. Glaciol. 2016, 57, 103-113. [CrossRef]

50. Pieczonka, T.; Bolch, T.; Wei, J.; Liu, S. Heterogeneous mass loss of glaciers in the Aksu-Tarim Catchment (Central Tien Shan) revealed by 1976 KH-9 Hexagon and 2009 SPOT-5 stereo imagery. Remote Sens. Environ. 2013, 130, 233-244. [CrossRef] 
51. Nuth, C.; Kääb, A. Co-registration and bias corrections of satellite elevation data sets for quantifying glacier thickness change. Cryosphere 2011, 5, 271-290. [CrossRef]

52. Berthier, E.; Arnaud, Y.; Kumar, R.; Ahmad, S.; Wagnon, P.; Chevallier, P. Remote sensing estimates of glacier mass balances in the Himachal Pradesh (Western Himalaya, India). Remote Sens. Environ. 2007, 108, 327-338. [CrossRef]

53. Shangguan, D.H.; Bolch, T.; Ding, Y.J.; Kröhnert, M.; Pieczonka, T.; Wetzel, H.U.; Liu, S.Y. Mass changes of Southern and Northern Inylchek Glacier, Central Tian Shan, Kyrgyzstan, during 1975 and 2007 derived from remote sensing data. Cryosphere 2015, 9, 703-717. [CrossRef]

54. Gardelle, J.; Berthier, E.; Arnaud, Y.; Kääb, A. Region-wide glacier mass balances over the Pamir-Karakoram-Himalaya during 1999-2011. Cryosphere 2013, 7, 1263-1286. [CrossRef]

55. Paul, F.; Barrand, N.E.; Baumann, S.; Berthier, E.; Bolch, T.; Casey, K.; Frey, H.; Joshi, S.P.; Konovalov, V.; Le Bris, R.; et al. On the accuracy of glacier outlines derived from remote-sensing data. Ann. Glaciol. 2013, 54, 171-182. [CrossRef]

56. Østrem, G.; Brugman, M. Glacier Mass-Balance Measurements: A Manual for Field and Office Work. In NHRI Science Report 4; Environment Canada National Hydrology Research Institute: Saskatoon, SK, Canada, 1991.

57. Wagnon, P.; Vincent, C.; Arnaud, Y.; Berthier, E.; Vuillermoz, E.; Gruber, S.; Ménégoz, M.; Gilbert, A.; Dumont, M.; Shea, J.M.; et al. Seasonal and annual mass balances of Mera and Pokalde glaciers (Nepal Himalaya) since 2007. Cryosphere 2013, 7, 1769-1786. [CrossRef]

58. Cuffey, K.M.; Paterson, W.S.B. The Physics of Glaciers, 4th ed.; Academic Press: New York, NY, USA, $2010 ;$ pp. 1-704.

59. Benn, D.I.; Evans, D. Glaciers and Glaciation, 2nd ed.; Hodder-Arnold: London, UK, 2010; 802p.

60. Zemp, M.; Thibert, E.; Huss, M.; Stumm, D.; Rolstad Denby, C.; Nuth, C.; Nussbaumer, S.U.; Moholdt, G.; Mercer, A.; Mayer, C.; et al. Reanalysing glacier mass balance measurement series. Cryosphere 2013, 7, 1227-1245. [CrossRef]

61. Banerjee, A. Brief communication: Thinning of debris-covered and debris-free glaciers in a warming climate. Cryosphere 2017, 11, 133-138. [CrossRef]

62. Dehecq, A.; Gourmelen, N.; Gardner, A.S.; Brun, F.; Goldberg, D.; Nienow, P.W.; Berthier, E.; Vincent, C.; Wagnon, P.; Trouvé, E. Twenty-first century glacier slowdown driven by mass loss in High Mountain Asia. Nat. Geosci. 2019, 12, 22-27. [CrossRef]

63. Brun, F.; Wagnon, P.; Berthier, E.; Shea, J.M.; Immerzeel, W.W.; Kraaijenbrink, P.D.A.; Vincent, C.; Reverchon, C.; Shrestha, D.; Arnaud, Y. Ice cliff contribution to the tongue-wide ablation of Changri Nup Glacier, Nepal, central Himalaya. Cryosphere 2018, 12, 3439-3457. [CrossRef]

64. Sakai, A.; Fujita, K.; Duan, K.; Pu, J.; Nakawo, M.; Yao, T. Five decades of shrinkage of July 1st glacier, Qilian Shan, China. J. Glaciol. 2006, 52, 11-16. [CrossRef]

65. Cao, B.; Wang, J.; Pan, B.; Zhang, X.; Cui, H. Surface flow velocities of the Ningchanhe No. 1 and Shuiguanhe No. 4 glacier in the East Qilian Mountains. J. Glaciol. Geocryol. 2013, 35, 1428-1435. (In Chinese)

66. Yao, T.; Thompson, L.; Yang, W.; Yu, W.; Gao, Y.; Guo, X.; Yang, X.; Duan, K.; Zhao, H.; Xu, B.; et al. Different glacier status with atmospheric circulations in Tibetan Plateau and surroundings. Nat. Clim. Chang. 2012, 2, 663-667. [CrossRef]

67. Li, J.; Li, Z.-w.; Zhu, J.-j.; Li, X.; Xu, B.; Wang, Q.-j.; Huang, C.-1.; Hu, J. Early 21st century glacier thickness changes in the Central Tien Shan. Remote Sens. Environ. 2017, 192, 12-29. [CrossRef]

68. Azam, M.F.; Wagnon, P.; Berthier, E.; Vincent, C.; Fujita, K.; Kargel, J.S. Review of the status and mass changes of HimalayanKarakoram glaciers. J. Glaciol. 2018, 64, 61-74. [CrossRef]

69. Wu, K.; Liu, S.; Jiang, Z.; Xu, J.; Wei, J. Glacier mass balance over the central Nyainqentanglha Range during recent decades derived from remote-sensing data. J. Glaciol. 2019, 65, 422-439. [CrossRef] 